\title{
MAKNA HIDUP BAGI PENGIKUT AJARAN TAREKAT QADIRIYAH WA NAQSYABANDIYAH (TQN) DI SUKAMARA KALIMANTAN TENGAH
}

\begin{abstract}
Soleha
Forum Studi Islam dan Isu-isu Lokal (FOSIIL) Sukamara-Kalimantan Tengah Alumni Jurusan Tasawuf dan Psikoterapi Fakultas Ushuluddin UIN Walisongo e-mail: soleha@gmail.com
\end{abstract}

\begin{abstract}
Abstrak: Tarekat Qadiriyah wan Naqsyabandiyah yang ada di desa Sungai Pasir Kecamatan Pantai Lunci Kabupaten Sukamara Kalimantan Tengah merupakan salah satu komunitas tarekat yang memiliki ruang gerakan dalam menyebar luaskan serta melestarikan ajaran sufi dengan menggunakan metode dzikir sebagai bentuk pelaksanaan dari ajaran tasawuf. Selain menjalankan aktifitas ritual para anggota tarekat ini juga memiliki dimensi kehidupan yang salah satunya adalah melakukan pemahaman terhadap kehidupan bermakna. Hal ini menjadi sebuah tolak ukur penting dalam meneliti perkembangan keagamaan yang ada di Indonesia. Komunitas tarekat yang ada di desa Sungai Pasir pada dasarnya memiliki ikatan emosional sesama anggota tarekat dengan ikatan normatif yang ada di dalam kelompok mereka sesuai dengan ajaran yang ada di dalam tasawuf. Namun demikian mereka juga memiliki tujuan dari sebuah komunitas yang salah satunya adalah mencapai ridha Tuhan.
\end{abstract}

Keywords: Sukamara, Makna Hidup, Victor Frankl, Guru, murid, manaqiban, dzikir. 


\section{A. Pendahuluan}

Tarekat adalah suatu metode atau penghayatan khazanah kerohanian (esoterisme $)^{1}$, dalam Islam dan salah satu pusaka keagamaan yang penting, yang harus ditempuh seorang salik (orang yang meniti kehidupan sufistik), dalam rangka membersihkan jiwanya sehingga dapat mendekatkan diri kepada Allah. karena tarekat mampu mempengaruhi perasaan dan pikiran kaum muslimin serta memiliki peranan yang sangat penting dalam proses pembinaan mental beragama masyarakat yang selama ini merasa terbelenggu oleh berbagai kecenderungan materialistik dan nihilism modern yang orientasinya mengacu kepada kemudahan, kenyamanan dan fasilitas hidup yang menyenagkan serta dapat menikmati dengan leluasa yang pada kenyataannya tidak selalu mendatangkan kesejahteraan dan kebahagiaan umat. Namun justeru pada sebagian orang yang menganutnya menimbulkan ketenangan jiwa dan kemampuan spiritual bagi dirinya. ${ }^{2}$

Studi tentang tarekat ini merupakan angapan bahwa pola-pola pikiran dan kegiatan tarekat disini dianggap sebagai bagian dari Agama Islam yang mengandung sistim kenyakinan (iman), sistim peribadatan (syari'at), dan sistim akhlak dan budi pekerti (ihsan), sesuai dengan kenyakinan para pengamal tarekat di Desa Sungai Pasir ini, bahwa

\footnotetext{
${ }^{1}$ Asmaran As, Pengantar Studi Tasawuf, Jakarta: PT Raja Grafindo Persada, 1994, h. vii

2Muchsin Jamil, Terekat dan Dinamika Sosial Politik: Tafsir Sosial Sufi Nusantara, Yogyakarta: Pustaka Pelajar, 2005, h. 43.
}

tarekat merupakan kesatuan sikap dan ajaran yang tidak bertentangan dengan syari'at islam.

Dengan adanya kegitan tarekat tersebut, masyarakat mengalami perubahan dan kemajuan yang pesat baik dalam pemahaman, penghayatan, peng-amalan ajaran Agama yang bersifat ukhrawi saja tetap juga teraflikasi pada aspek kehidupan duniawi. Hal ini dengan sendirinya mengantarkan pada upaya untuk menjauhi segala larangan Allah dan menjalankan semua perintah-Nya secara suka rela. Ini yang kemudian dipahami sebagai pengaruh tak langsung menemukan kebermaknaan hidup. Tandanya adalah mereka bisa menghargai hidup dan memanfaatkannya dengan perilaku dan perbuatan yang sesuai dengan ajaran Islam. Firman Allah Swt:

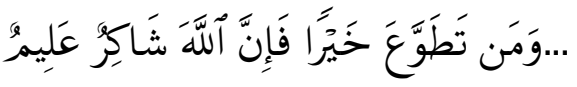

"Barangsiapa yang mengerjakan suatu kebajikan dengan kerelaan hati, maka sesungguhnya Allah Maha Mensyukuri kebaikan lagi Maha Mengetahui". (QS. al-Baqarah/2 : 158).

Menurut Frankl, kebermaknaan hidup adalah sebuah kehidupan manusia untuk memilih sebuah komitmen kehidupan. Maka, hidup ini bermula dengan adanya alasan, mengapa seseorang tetap hidup. Kebermaknaan hidup dapat diwujudkan pada nilai guna bagi orang lain, apakah anak, istri, keluarga dekat, komunitas negara atau 
bahkan umat manusia. ${ }^{3}$ Seseorang yang memiliki rasa hidup bermakna akan memiliki sebuah komitmen untuk hidup yang berarti dan berguna, baik untuk diri sendiri, orang lain, keluarga, maupun masyarakat. ${ }^{4}$ Komitmen adalah keadaan seseorang yang memegang teguh akan tujuan yang dicapainya suatu saat nanti. Untuk mencapai suatu kehidupan yang bermakna maka perlu adanya tujuan dan komitmen dalam hidup individu. Setiap individu pasti memiliki rasa kebermaknaan dalam hidupnya. Dalam mencapai sebuah tujuan akan hidup, mereka hidup untuk apa dan apa yang akan dilakukan dalam hidupnya untuk menuju hidup yang lebih bermakna. ${ }^{5}$

Bustami menyatakan bahwa makna hidup merupakan suatu yang dianggap penting, benar dan didambakan serta memberi nilai khusus bagi seseorang. Makna hidup bila berhasil ditemukan dan dipenuhi akan menyebabkan kehidupan ini terasa begitu berarti dan beharga. Pengertian makna hidup menunjukkan bahwa di dalamnya terkandung juga tujuan hidup, yakni hal-hal yang perlu dicapai dan dipenuhi. Maka hidup ini benar-benar terdapat dalam kehidupan itu sendiri, walaupun dalam kenyataannya tidak mudah ditemukan karena sering tersirat dan tersembunyi di

${ }^{3}$ Victor E. Frankl, Logoterapi Terapi Psikologi Melalui Pemaknaan Eksistensi, Terj. Man's Search Meaning: An Introduction to Logotherapy, Jogjakarta: Kreasi Wacana, 2006, h. vii-viii.

${ }^{4}$ H.D. Bastaman, Logoterapi: Psikologi Untuk Menemukan Makna Hidup dan Meraih Hidup Bermakna, Jakrta: PT Raja Grafindo Persada, 2007, h. 42 .

5Ibid., h.153. dalamnya. Bila makna hidup ini berhasil ditemukan dan dipenuhi akan menyebabkan kehidupan dirasakan bermakna dan berharga yang pada gilirannya akan menimbulkan perasaan bahagia $^{6}$.

Dengan demikian dapat diketahui bahwa berbagai krisis yang menimpa kehidupan manusia mulai dari krisis sosial, krisis struktural, sampai krisis spiritual, semuanya bermuara pada persoalan makna hidup manusia. Modernitas dengan segenap kemajuan teknologi dan pesatnya industrialisasi membuat manusia kehilangan orientasi. Kekayaan materi kian menumpuk, tapi jiwa mengalami kekosongan. Seiring dengan logika dan orientasi yang kian modern, kerja dan materi lantas menjadi aktualisasi kehidupan masyarakat. ${ }^{7}$ Gagasan tentang makna hidup ini menjadi pedoman dan gagasan dalam menentukan kehidupan yang optimal dalam menuju kebahagiaan dalam menjalankan kehidupan.

\section{Tarekat Qodiriyah Wan}

\section{Naqsyabandiyah Di Desa Sungai Pasir}

\section{a. Sejarah Tarekat Qodiriyah Wan Naqsyabandiyah}

Tarekat adalah gerakan sufi di mana umat Islam mengamalkan aktivitas keagamaan dengan menjalankan wirid tertentu. Kata tarekat merupakan serapan dari bahasa Arab, thariqah, yang secara harfiyah berarti jalan untuk mendekatkan diri pada Allah. Para anggota tarekat

6Ibid.,.h. 45-47.

${ }^{7}$ Said Agil Siraj, Tasawuf Sebagai Krisis Sosial Mengedepankan Islam Sebagai Inpirasi Bukan Aspirasi, Bandung: PT Mizan Pustaka, 2006, h. 48 . 
melakukan sebuah aktivitas yang dinamai wirid dzikir (laa ilaaha illallah/AllahAllah) di lisan dan di hati. Tujuan wirid dikarenakan tersebut untuk menempatkan diri mereka lebih dekat bersama Allah. Dzikir adalah suatu bentuk ibadah sufi khusus sebagai bentuk amalan wirid, yang berarti mengingat Allah. ${ }^{8}$

sejarah Thariqah Qadiriyah Wan Naqsabandiyah di Desa Sungai Pasir kecamatan Pantai Lunci kabupaten Sukamara Kalimantan Tengah, yang dipimpin oleh Syeikh KH Muhammad Aly Bahruddin yang berasal dari PONPES AtTaqwa Cabean Kejayan Pasuruan Jawa Timur. Beliau lahir di Desa Cabean Kejayan Pasuruan pada tahun 1962. Tarekat yang dibawanya memilki mata rantai langsung dari Nabi Muhammad Saw. Beliau menerima bai'at langsung dari gurunya, Syekh Muhammad Adlan Aly r.a. Cukir Jombang.

Bagi jama'ah TQN di desa Sungai Pasir, para jama'ah tidak terlepas dari Islam, Iman, ihsan atau yang biasa disebut dengan syari'ah, tarekat dan hakiqah. Serta mereka mempunyai kemauan yang keras untuk mengamalkan tarekat dan mempunyai sikap sebagai berikut::

1) Percaya bahwa TQN di desa Sungai Pasir itu sebagi tarekat yang benar untuk mendekatkan diri kepada Allah Swt.

2) Percaya pada guru TQN di desa Sungai Pasir sebagai orang yang bisa membimbing dalam menapaki jalan

${ }^{8}$ Endang Turmudi, Perselingkuhan Kiai dan Kekuasaan, (Yogyakarta. LKIS: 2004), h. 6263. spiritual keagamaan dalam mendekatkan diri pada Allah Swt. Serta mengamalkan nasehat guru yang dapat membangun dalam menjalankan ibadah kepada Allah Swt.

3) Tekun dan selalu mengamalkan dzikir TQN di desa Sungai Pasir (dzikir khafi dan jahr) sebagai yang diajarkan oleh tarekat melalui guru dan selalu bersedia mengamalkan dan mengikuti kegiatan-kegiatannya. Seperti Khususiyah dan Manaqib.

Kebahagiaan lahir batin bagi jama'ah TQN di desa Sungai Pasir adalah mengamalkan ajaran tarekat secara sungguh-sungguh, yang berintikan pada dzikir, serta amalan-amalan yang sudah di dapat di tarekat. ${ }^{9}$

Tarekat Qodiriyah Wan Naqsyabandiyah di desa Sungai Pasir ini, merupakan salah satu Jam'iyyah Ahlith Thariqah Mu'tabarah Qodiriyah Wan Naqsabandiyah. Jam'iyyah ini terbentuk pada tanggal 20 Juli 2004 M. Tarekat Qadhiriyah wan Naqsyabandiyah yang di ajarkan oleh KH Muhammad Aly Bahruddin adalah merupakan tarekat yang berada di bawah naungan Jamiyyah Ahlith Thariqah Al Mu'tabarah An Nahdiyyah,

Jam'iyah Ahlith Thariqah Al Mu'tabarah An Nahdliyyah adalah sebagai organisasi yang modern, profesional, berdaya guna serta mampu memberdayakan jama'ah melalui konsolidasi dan pengembangan organisasi, pendidikan dan pengkaderan,

9 Wawancara dengan beberapa jama'ah di desa Sungai Pasir, Jum'at 09 November 2012. 
dakwah dan kerjasama, serta pengembangan pemikiran Islam dalam rangka mereaktualisasikan ajaran Islam Ahlussunnah Wal Jamaah untuk mewujudkan nilai-nilai Islam yang Rahmatan lil alamin dalam kehidupan bermasyarakat, berbangsa dan bernegara.

Ada dua kriteria utama bagi tarekat untuk bisa disebut mu'tabarah. Pertama, ajaran-ajaran tarekat harus sesuai dengan syari'ah Agama Islam serta lebih berhatihati dalam menjalankan hukum Allah Swt. Kedua, wirid dzikir yang diamalkan harus berasal dari mata rantai yang tidak terputus antara mursyid dengan Nabi Muhammad. Arti mu'atabarah sendiri adalah terikat yang bersambung sanadnya sampai pada Rasulullah Saw, di mana beliau menerima dari Malaikat Jibril as., dan Malaikat Jibril as. Berasal dari Allah swt. 10

\section{b. Struktur Tarekat Qodiriyah Wan Naqsyabandiyah}

Secara umum struktur tarekat di desa sungai pasir terdiri dari pemimpin dan pengikut. Pemimpin dalam tarekat dinamakan Mursyid yang bertindak selaku pembimbing utama dalam berbagai aktivitas tarekat. Mursyid mempunyai pembantu yang disebut sebagai khalifah, yang tugasnya menggantikan tugas-tugas mursyid jika berhalangan. Selain sebagai pemimpin dalam berbagai aktifitas tarekat, mursyid bertugas memberi ijazah bai'at kepada

${ }^{10}$ Lihat dari kitab Pembinaan Moral Untuk Menjadikan Manusia Seutuknya Oleh Jam'iyah Ahlith Thoriqoh Mu'tabaroh Qodiriyah Wan Naqsyabandiyah, Cabean Kejayan Pasuruan Jawa Timur Indonesia, h. 58. para pengikut atau yang disebut murid. Namun di desa sungai pasir ini belum memiliki daftar anggota beserta struktur yangdisusun secara rigid, karena kebanyakan dari kegiatan dan aktivitas yang dilakukan berdasarkan atas kultural serta hubungan antara murid dan Guru saja. Hal ini seperti yang disampaikan oleh salah satu pengikut tarekat :

"Mengenai struktural yang ada di lembaga kami belum disusun secara rapi, serta angota-anggotanya belum ada daftar. Namun untuk membuat struktur dan mendata anggota tarekatnya, disini sudah dilakukan, namun belum ada secara resmi di bukukan hanya sebatas ancangan sementara untuk kelancaran pelaksanaan kegiatan ini saja, padahal dengan adanya struktur keanggotaan akan lebih mudah, hal ini bertujuan untuk mewadai warga tarekat salah satunya bila teroganisir akan lebih mudah dilindungi oleh pemerintah. Namun di sini belum dibuat mengenai strukturnya, namun masih diusahakan."11

Juga dikatakan oleh bapak Husain bahwa:

"Para pengikut tarekat di desa sungai pasir terdiri dari para masyarakat di daerah sekitar Kalimantan tengah. Para masyarakat secara keseluruhan tidak diwajibkan menjadi jama'ah tarekat, akan tetapi lebih diarahkan untuk mengikutinya, mereka yang memiliki kehendak menjadi anggota tarekat, maka ikut bai'at terlebih

11Wwancara dengan Bapak Syahrudin salah satu jama'ah tarekat pada Rabu, 31 Oktober 2012. 
dahulu dan mempertangung jawabkannya".12

Kebanyakan yang mengikuti thariqah ini adalah sudah berkeluarga atau orang yang sudah tua, Baik dari kalangan menengah kebawah atau ekonomi tingkat atas. Sedangkan istilahistilah dalam thariqah ini adalah; mursyid, murad, syaikh, pir, badal (pengganti), khalifah (maksudnya juga pengganti), pengikut atau murid, fakir, atau sering disebut darwisy. Seperti itulah yang digambarkan pada thariqah di desa sungai pasir. Kemudian ajaran thariqah diajarkan kepada muridnya dengan melalui bai'at (janji) untuk diberikan tanggung jawab. Seperti yang dikatakan bapak Husain bahwa:

"Adapun yang menjadi penganti mursyid di desa Sungai Pasir ini adalah Ustadz Sya'roni, Ustadz Budiono, dan Bapak Padlam, karena mereka yang sudah dianggap mampu untuk mengamalkan dan menjaga amalan terekat tersebut, maka diangkat sebagai penganti dalam mengamalkan aktivitas ajaran tarekat di desa ini. dari sinilah pengganti-pengganti itu mulai mengajarkan aktivitas ajaran thariqah Qadiriyah Wan Naqsabandiyah kepada para pengikutnya. Akan tetapi masalah pembe'atan pertama kali tetap sang mursyid yang membe'atnya, maka seorang yang sudah ikut bai'at, sudah menjadi pengikut tarekat dan

12Wawancara dengan Bapak Padlam salah satu jama'ah tarekat pada Rabu, 08 September 2012. wajib mengamalkan dan menjaga amalan-amalan yang ada di dalam aktivitas tarekat tersebut. Sedangkan tugas seorang penganti dalam menjalankan aktivitas tarekat, apabila sang mursyid tidak ada di tempat atau berhalangan."13

\section{c. Silsilah Tarekat Qodiriyah Wan Naqsyabandiyah}

Ajaran tarekat yang diikuti dan dikembangkan di desa Sungai Pasir adalah tarekat Qadiriyah wan Naqsyabandiyah, seperti yang terlihat pada jalur silsilah yang diikutinya.

Silsilah dalam dunia Tarekat menghantarkan sanadnya (mata rantai) menghubungkan mursyid yang satu dengan mursyid yang lainnya hingga Rasulullah Saw, bahkan sampai kepada Allah Swt. Mursyid atau guru tarekat di desa Sungai Pasir ini adalah $\mathrm{KH}$ Muhammad Aly Bahruddin, mengambil tarekat dari Syeikh Muhammad Adlan Aly Jombang, dan menempati urutan silsilah yang ke- 45 apabila dihitung dari matarantai pertama Allah Swt.

Secara skematis sanad silsilah Tarekat Qodiriyah Wan Naqsabandiyah yang ada di Desa Sungai Pasir ini dapat dilihat sebagai berikut:

1. Robbul Arbaabi wa Mu'tiqu Riqoobi Allah Swt.

2. Sayyiduna Jibril 'Alaih al-Salam.

3. Sayyidul Mursalin Sayyiduna Muhammad Saw.

13Wawancara dengan bapak Husain salah satu pengikut tarekat Qodiriyah Wan Naqsyabandiyah di Desa Sungai Pasir pada Senin, 05 November 2012. 
4. Sayyid Aly bin Abi Tholib Karromallahu Wajha

5. Sayyid Khusaini bin Fatimatuz Zuhro. $r, a$.

6. As Syekh Zainul 'Abidin. r.a.

7. As Syekh Mumammad Al Baqir. r.a.

8. As Syekh Ja'far Shadiq r.a.

9. As Syekh Musa Al Kadhim r.a.

10. As Syekh Abil Hasan 'Aly bin Musa Ar Ridho r.a.

11. As Syekh Ma'ruf Karkhi r.a.

12. As Syekh Sri Saqoti r.a.

13. As Syekh Abil Qosim Junaidi Al Baqhdadi r.a.

14. As Syekh Abi Bakar As Syibli r.a.

15. As Syekh Abdul Wahid At Tamimi r.a.

16. As Syekh Abil Faroj Al Turtusi r.a.

17. As Syekh Abil Hasan Al Hakari r.a.

18. As Syekh Abi Sa'id Al Mubarok Al Muhzir r.a.

19. Sayyidul Auliya' As Syekh Abdul Qodir Jaelani r.a.

20. As Syekh Abdul Aziz r.a.

21. As Syekh Muhammad Hattak r.a

22. As Syekh Samsuddin r.a.

23. As Syekh Syarofuddin r.a.

24. As Syekh Zainuddin r.a.

25. As Syekh Nuruddin r.a.

26. As Syekh Waliyuddin r.a.

27. As Syekh Hisyamuddin r.a.

28. As Syekh Yahya r.a.

29. As Syekh Abi Bakar r.a.

30. As Syekh Abdur Rochim r.a.

31. As Syekh Ustman r.a.

32. As Syekh Kamaluddin r.a.

33. As Syekh Abi Fatah r.a.

34. As Syekh Murod r.a.

35. As Syekh Syamsuddin r.a.

36. As Syekh Akhmad Khatib Sambas r.a.

37. As Syekh Abdul Karim Banten r.a.
38. As Syekh Ahmad Hasbullah r.a.

39. As Syekh Asnawi Banten r.a.

40. As Syekh Kholil Rejoso Jombang r.a.

41. As Syekh Abdul Latif Banten r.a.

42. As Syekh Romli Tamim r.a.

43. As Syekh Muslich Abdur Rohman r.a.

44. As Syekh Muhammad Adlan Aly r.a. Cukir Jombang.

45. KH. Muhammad Aly Bahruddin Pon Pes "AT TAQWA" Cabean Kraton Pasuruan Jawa Timur Indonesia. ${ }^{14}$

Dari uraian silsilah yang diterima KH Muhammad Aly Bahruddin dari gurunya Syeikh Muhammad Adlan Aly seorang ulama kharismatik dan banyak menelurkan bayak ulama besar di antara salah satunya adalah KH Muhammad Aly Bahruddin.

\section{d. Tujuan Tarekat Qodiritah Wan Naqsyabandiyah}

Adapun tujuan didirikannya tarekat di Desa Sungai Pasir, adalah sebagai beikut:

1. Membaca (mengamalkan) kalimat alQur'an, sebab lafadz la ilaha illa Allah itu , kalimat al-Qur'an.

2. Taubat: sebab lafadz la ilaha illa Allah untuk melebur dosa.

3. Tawasul dengan berdzikit dan Menjalankan perintah Allah yang ada di dalam Al-Qur'an, sebab orang-orang yang beriman diperintahkan untuk banyak berdzikir.

4. Menjalankan amalan dan perintah kanjeng Nabi, sebab Nabi ahli dzikir,

\footnotetext{
${ }^{14}$ Sumber dokumen Lihat dari kitab Pembinaan Moral Untuk Menjadikan Manusia Seutuknya Oleh Jam'iyah Ahlith Thoriqoh Mu'tabaroh Qodiriyah Wan Naqsabandiyah Cabean Kejayan Pasuruan Jawa Timur Indonesia. h. 149152.
} 
dan selalu berdzikir setiap waktu dengan sebanyak-banyaknya. Dan membersihkan hati baik dhahir maupun batin dari sifat-sifat madzmudah yang merusak amal dunia dan akhirat. Supaya bisa istiqomah menjalankan syari'at Agama dengan hati yang ihlas.

5. Dapat menguatkan iman, menghilangkan sifat munafik dan membentengi diri dari godaan syaithan dan menyelamatkan dari neraka.

6. Dapat meneruskan/mensiarkan amalan kanjeng Nabi, para wali-wali terutama syaikh Abdul Qodir Jaelani r.a, supaya mendapat pembelaan dan pertolongan dan digolongkan di dalam surganya. sebab thoriqoh Qodiriyah dan Naqsabandiyah dari Nabi menyambung kemalaikat Jibril dan berasal dari Allah.

7. Belas kasihan kepada keluarga kita yang telah meninggal, dengan berdzikir kalimat la ilaha illa Allah/Allah-Allah. Dan mengamalkan dan membiasakan diri dengan berdikir kepada Allah, yang paling utama, yaitu la ilaha illa Allah.

8. Menjauhkan diri dari rekayasa / sifatsifat syaitan, Supaya dapat beribadah dengan hati ikhlas, istiqomah dan menjadi orang yang bertaqwa. Dengan menenangkan hati, merukunkan keluarga, menenteramkan desa, mengamankan Negara, mensukseskan tujuan. ${ }^{15}$

Adapun faedah tarekat sangat besar, antara lain:
1. Diakui sebagai murid Syaikh Abdul Qodir al-Jaelani r.a.

2. Ditolong dan dibela di dunia dan akhirat oleh Syaikh Abdul Qodir alJaelani r.a.

3. Dimintakan maaf kepada Allah oleh Syaikh Abdul Qodir al-Jaelani r.a.

4. Dikumpulkan dengan Abdul Qodir alJaelani r.a di akhirat kelak. ${ }^{16}$

Adapun yang melatar belakangi setiap orang yang akan menjadi pengikut tarekat merupakan faktor yang berpengaruh secara signifikan. Hampir seluruh informan mengakui bahwa sebelum mengambil keputusan untuk masuk atau tidak menjadi pengikut Thariqah Qadiriyah Wan Naqsyabandiyah, terjadi suatu keadaan negatif yang menimpanya dan sangat sulit dihadapi dan dicari jalan keluarnya. Keadaan negatif yang dialami oleh satu individu dengan individu lainnya sangat beragam sesuai dengan sumber kejadian dan keadaan masing-masing. Oleh karena itu, secara sederhana dapat dikatakan bahwa pengetahuan seseorang tentang thariqah Qadiriyah Wan Naqsabandiyah hanya dianggap sebagai faktor penarik dan pembimbing dalam pengambilan keputusan. Adapun keadaan khusus yang menimpa individu sebelum mengambil keputusan, dianggap sebagai faktor pendorong dalam proses pertimbangan untuk mengambil keputusan apakah seseorang menjadi pengikut thariqah Qadiriyah wan Naqsabandiyah.

Secara teknis, seseorang yang akan menjadi pengikut thariqah Qadiriyah wan 
Naqsabandiyah, sekurang-kurangnya harus melalui lima tahap.

Pertama, seseorang telah menunjukkan niatnya untuk menjadi pengamal ajaran thariqah Qadiriyah Wan Naqsabandiyah. dia diperbolehkan ikut serta dalam setiap aktivitas yang diselenggarakan oleh komunitas thariqah Qadiriyah Wan Naqsabandiyah. Melalui tahapan ini, seorang pengikut dapat mulai memahami beberapa sifat dasar yang dimiliki oleh ajaran thariqah Qadiriyah Wan Naqsabandiyah.

Kedua, setelah ia merasa cocok, pada tahap berikutnya, mulai diberikan penjelasan kepadanya tentang ajaran thariqah secara lebih mendalam. Seorang guru menjelaskan beberapa hal berkenaan dengan ajaran thariqah Qadiriyah Wan Naqsabandiyah, tetapi tetap memberikan kebebasan kepada pengikut untuk menentukan sendiri, apakah ia akan melanjutkannya ke tahap berikutnya, atau masih membutuhkan orientasi, atau bahkan mengakhiri keterlibatannya dalam aktivitas tersebut.

Ketiga, setelah menetapkan niatnya untuk terus bergabung, ia disuruh melaksanakan shalat istikharah untuk memperoleh petunjuk dari Tuhan. Dengan bimbingan seorang guru atau badal seorang pengikut memohon petunjuk Allah. Selain dimaksudkan untuk mendapat petunjuk dan memperoleh barakah, secara psikologis melalui tahapan ini seorang pengikut juga bisa memperoleh dukungan moril sehingga niatnya semakin kuat dan penuh keyakinan.
Keempat, jika sudah mantap, ia diminta untuk menyatakan kesanggupannya untuk menaati semua ajaran dan ketentuan thariqah. Pernyataan kesanggupannya ini antara lain dilakukan dalam bentuk janji untuk tidak akan murtad. Hal ini didasarkan pada satu keyakinan bahwa barang siapa yang keluar dari thariqah Qadiriyah Wan Naqsabandiyah, ia harus berani menanggung akibat buruk berupa siksa Allah Swt.

Kelima, atau tahap terakhir, setelah keempat tahapan di atas dilalui, ia ditalqin dan dituntun oleh guru untuk membaca istighfar (minta ampun kepada Allah), membaca tahlil, shalawat, dan alFatihah masing-masing sebanyak seratus kali. Oleh karena itu, meskipun masih ada peluang untuk tidak melanjutkan kejamaahannya dalam komunitas thariqah Qadiriyah Wan Naqsabandiyah, proses talqin merupakan pintu gerbang isyarat masuknya seseorang ke dalam thariqah Qadiriyah Wan Naqsabandiyah. Setelah mengikuti proses talqin, seperti diakui oleh beberapa orang pengikut, muncul kesadaran spiritual baru yang mengantarkan pengalaman religiusitas yang tidak dirasakan sebelum melakukan talqin. ${ }^{17}$

Pada sisi lain, diketahui pula bahwa sebagian besar pengikut thariqah Qadiriyah Wan Naqsabandiyah adalah lapisan masyarakat kecil, seperti pedagang, petani, nelayan, yang kurang

17Wawancara dengan beberapa jama'ah tarekat Qadiriyah Wan Naqsyabandiyah yang telah melaksanakan kegiatan tarekat ini pada Jum'at, 02 Nopember 2012. 
mampu ekonominya dan latar belakang pendidikan sangat rendah. Demikian pula pada aspek pengetahuan agamanya, mereka dapat digolongkan masih awam. Rata-rata memperoleh pendidikan agama di tempat-tempat pengajian yang biasa diadakan di lingkungan rumahnya. Bahkan, ada sebagian yang baru mulai mempelajari agama beberapa waktu sebelum atau pada saat menjadi pengikut thariqah Qadiriyah Wan Naqsabandiyah. Dengan demikian, selain belajar wirid, mereka juga belajar shalat yang baik serta ibadah-ibadah mahdlah lainnya. Sekalipun demikian, secara praktis, mereka termasuk penganut agama mapan ilmu agamanya meningkatkan supaya bisa menjalankan ibadah kepada Allah dengan baik.

Permulaan seseorang menjadi pengikut/anggota suatu perkumpulan thariqah adalah bai'at atau janji setia dengan guru. Dalam kesempatan janji setia itulah guru atau kiai menyampaikan "rahasia" suluk amalannya. Setelah menerima rahasia suluk ini dia kini menjadi seorang ihwan atau saudara sesama anggota perkumpulan. Di Indonesia khususnya Jawa pemimpin thariqah it u disebut guru atau kiyai. Di Timur Tengah mereka disebut Mursyid (pemberi petunjuk), murad (orang yang dikehendaki atau dicari), syaykh (syeikh, orang tua), pir (bahasa persia, juga berarti orang tua). Pengikutnya disebut dengan murid (orang yang menuntut atau mencari kebenaran), faqir (orang miskin, maksudnya miskin rohani sebagai lawan dari Allah yang bersifat ghani yang berarti kaya).
Sesungguhnya setiap orang adalah faqir dalam arti memerlukan pertolongan Allah, juga disebut darwisy dalam bahasa Persia yang mempunyai arti sama dengan faqir. ${ }^{18}$ Karena gerakan thariqah- thariqah yang dipimpin seorang kiai atau guru meliputi daerah yang sangat luas, maka perlu diangkat wakil-wakil setempat yang disebut dengan badal (pengganti) atau khalifah (juga sebagai pengganti). Seperti yang di ungkapkan oleh beberapa anggota tarekat di Desa Sungai Pasir bahwa:

"Beberapa anggota yang memutuskan masuk thariqah Qadiriyah Wan Naqsabandiyah mengaku bahwa, tujuannya menjadi pengikut merupakan upaya untuk membebaskan diri dari ketegangan-ketegangan yang muncul di lingkungan sosial mereka, yang banyak diwarnai persaingan dan suasana ketidaknyamanan. Gejala ini banyak terjadi, terutama di kalangan masyarakat yang relatif langka suasana sosial keagamaan. Sebagian besar dari waktu hidupnya lebih banyak digunakan untuk memenuhi kepentingan materiil. Sebagian di antara mereka merasakan bahwa kehidupan yang dialaminya penuh dengan dosa dan kesalahan. Mereka mulai mencari jawaban atas ketidakpastian itu dan banyak di antaranya yang menemukan alternatif jawabannya setelah masuk menjadi pengikut thariqah Qadiriyah Wan Naqsabandiyah. Dengan mengamalkan ajaran-ajaran thariqah Qadiriyah Wan Naqsabandiyah, mereka dapat berusaha melepaskan diri dari rasa

${ }^{18}$ Nurcholid Madjid, Bilik-Bilik Pesantren (Sebuah Potret Perjalanan), (Jakarta: Paramadina, 1997), h. 61. 
bersalah yang menekan. Dengan demikian, zikir sebagai salah satu bentuk amalan thariqah, dapat dipandang sebagai terapi psikologis dalam menyelesaikan masalah-masalah rohaniah". ${ }^{19}$

Begitulah potret kecil yang melatarbelakangi seseorang memasuki dan mengikuti ajaran thariqah Qadiriyah Wan Naqsabandiyah di Desa Sungai Pasir tersebut.

\section{Amalan dan Ajaran Tarekat Qodiriyah Wan Naqsyabandiyah di desa Sungai Pasir}

\section{Bai'at (Talqin Dzikir)}

Bai'at atau 'ahad adalah kesanggupan dan kesetiaan seorang murid dihadapan gurunya untuk mengamalkan dan mengerjakan segala kebajikan yang diperintahkan. Sedangkan talqin adalah pengajaran guru kepada murid. Upacara pemberian Khirqah ${ }^{20}$ atau pentahbisan seseorang untuk menjai murid atau pengikut ajaran tarekat ini disebut dengan mubaya'at atau pen talqiman dzikir.

${ }^{19}$ Wawancara dengan beberapa anggota tarekat di Desa Sungai Pasir, pada Jum'at, 02 November 2012.

${ }^{20}$ Khirqah adalah "jumlah tambalan" yang menjadi symbol bagi salik (sang penumpuh jalan spiritual, jubah ini diberikan oleh mursyid kepada muridnya ketika ia mulai ditasbihkan kedalam tarekat atau ketika ia telah menyelesaikan perjalan ( suluk) nya. Khirqah hakiki adalah menutupi diri dengan penghambaan dan menengelamkan diri dalam cinta ('isyq). Lihat, Amatullah Amsrong, Kunci Memasuki Dunia Taswuf, (Bandang: Mizan, Cet. II, 1998), h. 146147. Yang terdapat di dalam buku karangan Zainul Adzfar, Epistimologi Pengalaman Keagamaan Dalam Tradisi Tarekat (Stadi Pengalaman Keagamaan Ikhwan Tarekat Qodiriyah Wa Naqsabandiyah (TQN) Di Suryalaya), 2006, h. 156.
Adapun tata cara dalam proses bai'at / talqin dzikir itu ditandai dengan diucapkannya lafadz-lafadz do'a secara bersama-sama antara mursyid dan para pengikut (murid). Lafadz-lafadz do'a yang dimaksud adalah:

a. Bismillah al rahman al rahim. Allahumma iftahlii bi futuhil 'arifin Sebanyak tujuh kali. (ألْعَارفِيْنَ )

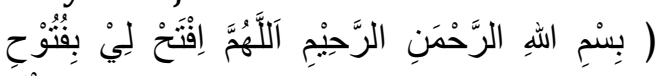

b. Bismillah al rahman al rahim, alhamdulillahi wa al shalatu wa alsalamu 'alaa sayidina Muhammad al haadi ila shirat al mustaqiim

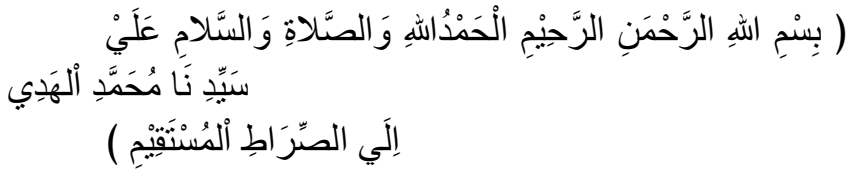

c. Bismillah al rahman al rahim, astaghirullah al 'adhi, Sebanyak tiga kali.

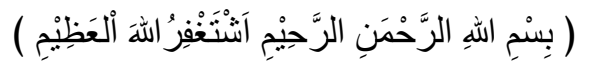

d. Allahumma shalli 'alaa sayyidinaa muhammad wa 'alaa 'aali Muhammad, Sebanyak tiga kali.

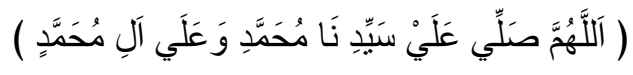

Setelah bacaan lafadz itu selesai, maka mursyid membaca dzikir nafi itsbat laailaha illalah (لالهالاله) sebanyak tiga kali yang diikuti oleh murid. Setelah membaca dzikir nafi itsbat itu prosesi bai'at diakhiri dengan membaca lafadz Muhammad al-Rasulullah ( محمدرسولله ) dan sholawat munjiyat yang dibaca oleh mursyid dan murid. ${ }^{21}$

21Proses bai'at pertam kali yang dilakukan di desa Sungai Pasir oleh KH. Muhammad Ali Bahruddin terhadap seseprang 
Peranan guru kerohanian, yang biasa disebut syaikh, mursyid, murad atau pir $^{22}$ adalah untuk menumbuhkan kelahiran rohani dan perubahan yang menjadikan seseorang ada pertalian melalui mata rantai (silsilah) dengan nabi Muhammad Saw. Tugas seorang mursyid terhadap murid adalah untuk mendidik dan membimbing, karena itu menjadi priritas utama dalam tarekat. Oleh karena itu hubungan antara mursyid dan murid sering kali dilukiskan sebagai hubungan antara kedua orang tua dan anak. Yang

yang inggin mengikuti tarekat, baik secara individu maupun berjamaah. Akan tetapi yang dilakukan di desa Sungai Pasir ini, di lakukan dengan cara berjamaah. di utarakan oelha Ust. Sya'roni pada tanggal 24 Oktober 2012.

${ }^{22}$ Bagi seorang mursyid disyaratkan memiliki tanggung jawab terhadap muridnya. a. Seorang mursyid haruslah seorang yang alim. b. Seorang mursyid haruslah'arif. c. Seorang mursyid harus sabar dan mempunyai rasa belas kasihan yang tinggi kepada murid-muridnya. d. Seorang mursyid harus pandai menyimpan rahasia muridmuridnya. e. Seorang mursyid tidak boleh menyalahgunakan kedudukan sebagai seorang guru spiritual atau orang yang paling tinggi martabatnya dalam tarekat. f. Seorang mursyid haruslah bijaksana. g. Seorang mursyid harus disiplin. h. Menjaga lisan dan nafsu keeduniaan. i. Seorang mursyid harus mempunyai hati yang ikhlas. j. Selalu menjaga jarak antara dirinya dengan muridnya. k. Memelihara harga diri, wibawa dan kehormatan. l. Mursyid harus bisa memberi petunjuk tertentu pada situasi tertentu kepada muridnya. m. Merahasakan hal-hal istimewa. n. Mursyid selalu mengawasi muridnya dalam kehidupan sehari-hari. o. Merahasiakan segala gerak gerik kehidupannya. p. Seorang mursyid harus mencegah berlebihan dalam makan dan minum. q. Seorang mursyid harus menyediakan tempat berkhalwat bagi muridmuridnya. r. Menutup pergaulan murid dengan mursyid lainnya. Lihat dalam kitab Sabilus Salikin Jalan Para Salik, panduan bagi salik thariqat Naqsabandiyah mujaddadiyah khalidiyah, oleh Bahrudi Zakaria, Segonagung: pondok pesantren ngalah, 2012, h. 102-105. salaing member pendidikan yang baik terhadap perkembangan dalam demensi kerohanian.

Oleh karena itu seorang mursyid tidak hanya memiliki kesempurnaan diri, tapi juga mampu mengantar orang lain kepada kesempurnaan; ia harus menjadi orang yang "terilluminasi" (Nurani) serta "mengulluminas" (nurbakhsy), tipe guru mistily adalah "kamil Muqallid" seorang syaikh yang sempurna lagi menyempurnakan, hanya saja kemampuannya mengantarkan orang lain kepada kesempurnaan masih bertaqlid kepada syaikh yang benar-benar sempurna lagi menyempurnakan. Hal ini karena ia mampu membebaskan manusia dari pembatasan-pembatasan dunia kebendaan yang sempit menuju ruang rohani yang terang dan tak terbatas. Bahkan guru bisa menjadikan adanya kematian dan kelahiran rohani yang terjadi karena barakah yang ada dalam dirinya. $^{23}$

Talqin harus dilakukan atau dipimpin oleh seorang Mursyid atau wakil talqin. Hal ini dilakukan karena makna talqin yang paling dalam adalah membangun "ruh qudsi" seseorang. Oleh karena itu tidak sembarang orang boleh melakukannya.

\section{Dzikir}

Ajaran dalam tarekat adalah dzikir yang lebih utama, Dzikir adalah sebuah media untuk mendekatkan diri kepada sang Khalik. Dzikir juga cara termudah dan paling dinamis untuk membersihkan diri dari beban, dzikir juga merupakan

23Zainul Adzfar Epistimologi..., h. 160. 
penawar racun apapun selain kebutuhan akan Allah, memberikan kekuatan diri menuju kesadaran yang tidak terjebak dualitas, penghubung langsung kepada Allah, membawa energy yang bisa melepaskan belenggu kehidupan dunia, karena semuanya selalu mengigatkan bahwa semuanya kepunyaan Allah semata. Hal demikian, dapat memunculkan rasa kebebasan dan kekuatan untuk mencapai sebuah tujuan yang lebih tinggi dalam mengarungi hidup yang penuh berarti. Dengan berdzikir hati menjadi tenang dan tentram, firman Allah الابذكراله تطمئن القلؤب (ketahuilah, dengan berdzikir hati menjadi tenang).

Dzikir adalah sebagai sarana terpenting dalam melakukan mi'raj rahani (pendakian spiritual), dan upaya pendekatan diri mereka kepada Allah Swt. Dzikir dalam TQN ini dilakukan setelah melaksanakan ibadah wajiban. Karena ibadah wajib merupakan penjabaran Syari'ah sedangkan dzikir merupakan pengalaman aspek batin dari Syari'ah yang dalam tasawuf disebut tarekat. Syari'at dan tarekat ini diamalkan secara seimbang dalam upaya mencari hakikat. Sebagai nalar bagi intuisi, sebagai iman terhadap penglihatan, dan merupakan kepatuhan yan penuh di dalam berserah diri kepada Allah Swt. ${ }^{24}$ Dzikir dapat berupa lantunan kalimat syahadat, yaitu la ilaha ilallah (tidak ada Tuhan selain Allah Swt), atau kalimatkalimat yang lainnya, seperti tasbih, do'a, dan lainnya.

${ }^{24}$ Abdul Hak Ansari, Antara Sufisme dan Syari'ah, terj. Ahmad Nashir Budiman, (Jakarta:Rajawali,1990), h. 274.
Dengan demikian, ajaran dzikir dalam tarekat ini selain bernilai ukhrawi, juga sangat bermanfaat menghindarkan diri dari berbagai penyakit baik fisik maupun batin. Yang sekarang banyak diderita oleh masyarakat modern, dengan demikian dzikir dapat difungsikan sebagai metode psikoterapi, karena dengan banyak melakukan dzikir jiwa seseorang akan menjadi tentram, serta tidak mudah terombang-ambing oleh lingkungan dan budaya global. Dengan membaca dzikir menurut kaidahnya dan sebanyak-banyaknya maka akan berdampak:

1) Mencegah dari segala sesuatau yang akan membahayakan.

2) Menyebabkan seseorang akan menjadi pemurah terhadap orang lain dan melakukan hal-hal yang bermanfaat bagi orang lain.

3) Menghilangkan semua rasa cemas dan rasa takut serta menghilangkan kemunafikan.

4) Menghilangkan dan menghancurkan kekuatan syetan.

5) Menarik mata pencaharian dan menjadikan peribadi yang terhormat.

6) Jalan menuju untuk dekat kepada Allah.

7) Sebagai obat bagi segala macam penyakit

8) Dapat memberi pertolongan terhadap manusia dunia akhirat.

Adapun tata cara dzikir dalam thariqah Qadiriyah Wan Naqsabandiyah sebagai berikut:

Ajaran pokok Tarekat Qadiriyah adalah membaca dzikir laa ilaaha illa Allah (لا اله الا الله) sebanyak 165 kali 
setelah melaksanakan shalat lima waktu. Cara membacanya dengan suara keras (Dzikir Jahr) secara bersama-sama atau sendirian. Sebelum melalui membaca Dzikir Qadiriyah didahului membaca istighfar sebanyak tiga kali atau lebih dan membaca shalawat kepada Nabi Muhammad saw tiga kali.

Adapun kaifiyah (tata cara) mengucapkan lafadz laa ilaaha illa Allah adalah sebagai berikut:

Dzikir "laa ilaaha illa Allah" sebanyak $165 \mathrm{X}$ dengan sikap: duduk (kebalikan dari duduk tasyahud akhir dalam shalat), kepala merunduk, mata terpejam, tangan kanan memegang tasbeh diletakan diatas lutut kanan untuk hitungan (165 X), tangan kiri diletakan diatas lutut kiri dan di tengadakan ke atas untuk mengharapkan rahmat Allah Swt dan didepan mata yang terpejam sambil membayangkan wajahnya guru yang membai'at dan guru yang membai'at membanyangkan wajahnya guru silsilah sampai Syech Abdul Qodir Al-Jaelani RA., hingga sampai Nabi Muhammad Saw. Karena beliau membantu menghantarkan dzikir kita kehadirat Allah Swt dan membantu mengusir syaithan juga membersihkan selaput hati kita dari kotoran dosa dan sifat Madzmudah jenis syara'.

Setelah itu menahan nafas, lalu Memanjangkan lafadz laa ( $\vee$ ) dengan memusatkan fikiran, ditarik dari pusat hingga ke otak; kemudian lafadz ilaaha ( ) ll ke kanan; dan lafadz ilallaah ( اله اله ) dijatuhkan kearah kiri dengan memelihara hati agar senantiasa ingat akan esensi kalimat musyarraqah itu, yaitu "tidak ada Tuhan yang berhak disembah selain Allah".

Setelah melafadzkan dzikir itu kemudian mengucapkan lafadz kalimah "Muhammad al Rasulullah" (لهمد الرسول له ) kemudian membaca do'a shalawat munjiyat dan di akhiri membaca do'a ${ }^{25}$ :

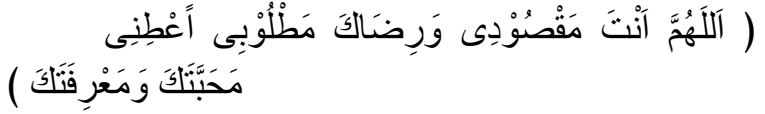

Sesudah berdo'a dilanjutkan dengan berwasilah dengan membaca surat $\mathrm{Al}-$ Fatihah yang ditujukan kepada ahli silsilah tarekat Qadiriyah khususnya Syeikh Abdul Qadir Al Jailani dan Abi Al Qasim Junaid Al Baghdadi. Kaifiyah (tata cara) mengawali dzikir Naqsyabandiyah sama dengan tata cara memulai dzikir tarekat Qadiriyah, yaitu diawali dengan melakukan tawasul. Urutan dalam melakukannya adalah sebagai berikut :

a. Duduk (kebalikan dari duduk tasyahud akhir dari shalat).

b. Membaca fatehah pertama ditujukan kepada junjungan Nabi yang terpuji yaitu Nabi Muhammad Saw, keluarga dan para sahabatnya.

c. Membaca fatehah kedua ditujukan kepada guru silsilsh Thariqah Qodiriyah Wan Naqsabandiyah khususnya kepada pimpinan wali Syekh Abdul Qodir Al-Jaelani dan Syekh Abil Qosim Junaidi Al-Baqdadi Qoddasalahu.

d. Membaca fatehah ketiga ditujaukan kepada bapak ibu kita dan bagi semua orang islam laki-laki dan bagi orang islam perempuan baik yang masih

25Kitab Pembina Moral..., h. 112 
hidup maupun yang sudah meninggal dunia (mati).

e. Membaca istighfar sebanyak tiga kali atau lebih, membaca surat Al- Ikhlas sebanyak tiga kali atau lebih, dan membaca shalawat Ibrahimiyah.

Sesudah bertawasul kepada masingmasing yang tersebut di atas, kemudian memulai membaca dzikir Naqsyabandiyah. Urutan dan tata cara melakukannya adalah sebagai berikut : Menghadapkan hati kepada Allah dengan wasithah kepada para guru mursyid (menggunakan perantara mursyid) yang telah memberikan ijazah dengan menghadirkan wajahnya dalam penglihatan hati yang seakan-akan berada di depannya.

Dzikir sirri (hati) lafadz Allah ( ل) dengan fikiran dihadapkan pada lathifah al qalb, yaitu halusnya hati yang bertempat dibawah dada kiri, sekitar dua jari agak miring ke kiri dengan mengingat dzat Allah yang sempurna, seraya menempatkan lidah pada langi-langit mulut dengan memejamkan mata dan menundukkan kepala. Setelah merasakan berubahnya dzikir pada lathifah al qalb, kemudian mengalihkan pusat perhatian pada lathifah ruh, yaitu halusnya ruh pada dada sebelah kanan, sekitar dua jari agak miring ke kanan, kemudian melakukan dzikir seperti pada lathifah al qalb.

Kemudian beralih kepada lathifah sirri, yaitu halusnya rasa yang berada pada dada kiri sebelah kanan sekitar rentangan dua jari yang miring pada dada, kemudian setelah merasakan perubahan perasaan mengalihkan perhatian pada lathifah al khaffi, yaitu halusnya nafsu yang tepat berada di dada kanan seberah kiri sekitar dua jari yang direntangkan miring ke dada, kemudian mengalihkan pusat perhatian pada lathifah al akhfa, yaitu halusnya nafsu yang lebih samar (halus) yang berada tepat ditengah dada, kemudian mengalihkan perhatian pada lathifah al nafsi, yaitu halusnya otak yang posisinya berada di antara dua mata dan dua alis, kemudian mengalihkan perhatian pada lathifah al qalib, yaitu halusnya keseluruhan anggota badan mulai dari ujung kepala hingga ujung telapak ke dua kaki, pada posisi tersebut berdzikir sirri dengan lafadz Allah ( له ) sebagaimana pada lathifah yang lain.

Pada dasarnya, lathifah-lathifah disini merupakan tempat illuminasi (pancara tetan ketuhanan), pusat "realitas". Dalam tarekat elemen ini diaktifkan sebagai "pencarian diri", juga sebagai sebuah teori keadaan fisik badaniyah, yang pada umumnya tetap mengacu "dimana pusat dari kekuatan yang sejati".

Setelah selesai melaksanakan dzikir dan dapat merasakan perubahan yang terjadi, maka aktifitas dzikir Naqsyabandiyah diakhiri dengan membaca do'a yang sama dengan do'a dibaca ketika mengakhiri dzikir dalam tarekat Qodiriyah. ${ }^{26}$

Amaliyah-amaliyah dalam TQN di desa Sungai Pasir sudah terorganisir secara baik putarannya, menejemen dan jadwal pelaksanaany. Hal ini menunjukan

${ }^{26}$ Ibid., h. 115. 
antusias dari para ikhwan terhadap amalan tarekatnya sangat besar.

Adapun kegiatan yang dilakukan jama'ah tarekat di desa Sungai Pasir ini, dilakukan setiap hari setelah melaksanakan shalat lima waktu, dan seminggu sekali pada hari jum'at, dilaksanakan $b a^{\prime} d a$ shalat jum'at secara berjama'ah, pada jum'at legi dilaksanakan secara bergantian dari masjid satu kemasjid yang lain. Juga dilaksanakan sebulan sekali penaqiban pada tagal 11 Hijriyah, serta Haulan Kubro setahun sekali, biasanya pada bulan Robiul Awal (bulan maulud). Dengan mendatangkan seorang guru/mursyid dari ponpes AtTaqwa pasuruan Jatim. Dengan tujuan untuk membimbing spiritual kerohanian bagi masyarakat setempat dalam menempuh kehidupan yang lebih berguna dan bermakna, semata-mata dalam rangka menjalankan ibadah kepada Allah. Karena dengan adanya bimbingan tersebut seseorang lebih mudah memahami arti kehidupan yang sesungguhnya, dapat dengan mudah dalam mengamalkan tuntunan syari'at.

Adapun amalan dzikir bagi ikhwan yang dilakukan secara rutin terbagi menjadi 3 (tiga) kategori, yaitu:

\section{a) Aktivitas Harian}

Aktivitas harian dilaksanakan setiap selesai melaksanakan shalat fardhu, yang berupa pembacaan dzikir yang harus dilaksanakan para jama'ah tarekat setiap hari, harus tartil, tidak boleh tergesa-gesa.

Untuk materi dzikir harian, yaitu: melafadzkan kalimat laa ilaaha illa Allah tiga kali dengan suara keras, kemudian membaca fatehah kepada nabi
Muhammad, kepada Syaikh Abd Qodir Jaelani, kepada keluarga besar Tarekat Qodiriyah Wan Naqsabandiyah, membaca Astagfirullaha Ghafururrahim tiga kali, membaca surat Al-Ikhlas tiga kali, surat al-Alaq dan an-Nas satu kali, membaca solawat Ibrohim, serta dilanjutkan dengan berdzikir dengan kalimat "Allah" di dalam hati, sabil duduk kebalikan duduk tawaruk pada waktu tahiyat pada shalat, bibir dirapatkan, lidah dilipat kebagian mulut paling dalam, gigi dirapatkan tidak ada bergerak dan menahan nafas sekuatnya, tangan diatas paha tangan yang kanan memegang tasbih agar mudah untuk menghitungnya dan tangan yang kiri ditelantangkan, kepala ditundukan ksebelah kiri (latifah al-Qolbi), serta fikiran selalu membayangkan wajah guru yang membai'atnya., dan hati selalu berdzikir Allah hingga menyatu keseluruh tubuh. Kemudian di akhiri dengan membaca:

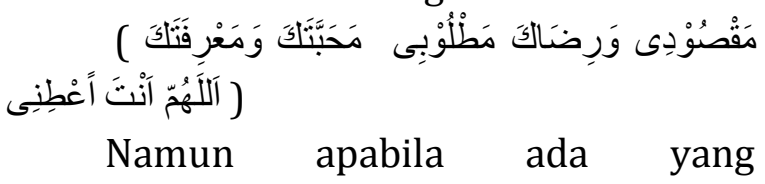
berhalangan, bertugas atau berada yang tidak memungkinkan maka cukup dengan membaca kalimat Tayyibah tiga kali, dan di kerjakan pada waktu yang luang. ${ }^{27}$

\section{b) Aktivitas Mingguan (Khususiyah)}

Aktivitas mingguan bagi para jama'ah tarekat di Desa Sungai Pasir di istilahkan dengan Khususi adalah suatu jama'ah yang ada amalan khusus thatiqah Qadiriyah wan Naqsyabandiyah. Aktifitasnya dilaksanakan setiap

27Wawancara dengan Bapak Amrullah pada Rabu, 31 Oktober 2012. 
seminggu sekali atau tujuh hari sekali pada hari Jum'at siang, setelah melaksanakan shalat jam'at. yang diikuti secara khusus oleh masyarakat pengikut Tarekat Qodiriyah Wan Naqsabandiyah setempat. Sebelum aktivitas yang berupa beberapa amalan dzikir dimulai di berikan dulu pengajian mengenai kitabkitab tasawuf seperti Al-Hikam karangan Ibn Ath'illah yang membahas sifat-sifat terpuji serta bagaimana cara untuk hidup di akhir zaman. Amalan khususi tersebut kalau kita berhalangan tidak hadir bisa kita amalkan dirumah sendiri/ditempattempat lain dalam waktu yang senggang. ${ }^{28}$ Setelah pengajian selesai mursyid atau penganti (badal) mulai membaca lafadz-lafadz dzikir yang diikuti oleh para jama'ah.

Adapaun urutan dari dzikir yang dibaca dalam aktivitas khususiyah ini adalah sebagai berikut :

1. Membaca surat al Fatihah sebanyak delapan kali yang ditujukan kepada Nabi Muhammad, para sahabat Nabi, silsilah ahli tarekat Qadhiriyah wa Naqsyabandiyah, kepada para guru dan semua muslim baik yang masih hidup maupun yang sudah meninggal.

2. Membaca shalawat Nabi, yaitu: "Allahumma shalli 'alaa sayyidinaa Muhammadin nabiyyil ummiyi wa'alaa'aalihii wa shahbihi wa sallim". Sebanyak 100 kali.

3. Membaca surat "alam Nasyrah" sebanyak 79 kali.

${ }^{28}$ Kitab Pembinaan Moral..., h. 90.
4. Membaca surat al Ikhlas sebanyak 100 kali.

5. Membaca surat al Fatihah yang ditujukan kepada semua guru tarekat satu kali.

6. Membaca shalawat Nabi seperti yang nomor 1 .

7. Membaca "Allahumma yaa Qadhiyal haajat." Wahaia Dzat yang mengabulkan berbagai permintaan, sebanyak 100 kali.

8. Membaca "Allahumma yaa kaasifal muhimmat" Wahai Dzat yang mencukupi kehendak, sebanyak 100 kali.

9. Membaca "Allahumma yaa raafi' al darajat" Wahai Dzat yang meninggikan beberapa derajat, sebanyak 100 kali.

10. Membaca Allahumma yaa daf'ul balliyaat, Wahai Dzat yang menolak bebrapa bencana, sebanyak tiga kali.

11. Membaca Allahumma yaa muhillal msykilaat, Wahai Dzat yang membebaskan berbagai kesukaran, sebanyak 100 kali.

12. Membaca "Allahumma yaa mujibadda'waat" Wahai Dzat yang mengabulkan beberapa permohonan, sebanyak 100 kali.

13. Membaca Allahumma yaa Syaafiyal amraad, Wahai Dzat yang menyembuhkan berbagai penyakit, sebanyak 100 kali.

14. Membaca Allahumma yaa arhamar rahimin, Wahai Dzat yang mempunyai kasih sayang, sebanyak 100 kali.

15. Membaca shalawat Nabi seperti nomor 1 . 
16. Membaca surat al Fatihah yang dihadiahkan kepada Imam Khawajikan satu kali.

17. Membaca surat al Fatihah yang ditujukan kepada Sheikh Abdul Qadir al Jailani satu kali.

18. Membaca shalawat Nabi seperti nomor 1 .

19. Membaca Hasbunallahu ni'mal wakiil, sebanyak 450 kali.

20. Membaca shalawat Nabi seperti nomor 1.

21. Membaca surat al Fatihah yang ditujukan kepada Syaikh Abdul Qadir al Jailani satu kali. dan Membaca surat al Fatihah yang ditujukan kepada semua guru tarekat sat kali.

22. Membaca shalawat Nabi seperti nomor 1.

23. Membaca Laa haula wa laa quwwata illaa billaahi, sebanyak 400 kali.

24. Membaca shalawat Nabi seperti nomor 1 .

Setelah bacaan ini, mursyid memberikan perintah kepada jama'ah untuk berhenti sejenak, sambil menundukan kepala dengan mata memejam sambil hatinya bergetar "Allah-Allah" dengan memohon ampun untuk keluarga dan semua jam'iyah tarekat semoga semua keluarga diampuni dosanya, diterima segala amalnya dan dihasilkan semua tujuannya, di selamtkan dari malapetaka di dunia dan di akhirat dan ditakdirkan bisa haji ke Baitullah. Dan semoga ditentramkan keluarganya, masyarakatnya, diamankan negaranya dan diberi keturunan yang bisa meneruskan amal kebaikannya juga jadi kebanggaan kita di duni dan akhirat. Dan diwafatkan husnul khatimah dan dimasukan surga tanpa hisab. Amin ya Rabbal 'Alamin dan kita merasa paling rendah-rendahnya makhluk serta menganggap diri kita berada dibawah telapak kaki semua makhluk. Setelah selesai bacaan do'a tersebut, mursyid mengakhiri membaca do'a yang diikuti oleh para murid, yaitu;

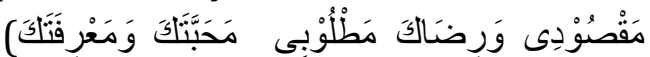

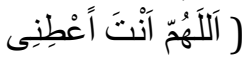

Kemudian mursyid dan para murid melanjutkan membaca dzikir berikutnya, yaitu:

25. Membaca surat al Fatihah pada guru silsilah Tharqoh mu'tabaroh Qodiriyyah wan Naqsabandiyyah satu kali.

26. Membaca shalawat Nabi seperti nomor 1.

27. Membaca yaa Lathiif, sebanyak 129 kali.

28. Membaca shalawat Nabi seperti nomor 1 .

29. Membaca surat al Fatihah yang ditujukan kepada Nabi Muhammad, para keluarganya, dan para sahabatnya, serta para guru-guru dan semua umatnya 1 kali.

30. Membaca dzikir Qodiriyah yaitu: la ilaha illa Allah, sebanyak 165 kali.

31. Dzikir Naqsabandiyyah yaitu getaran hati kalimat Allah-Allah, sebanyak 1000 kali. 
Masuknya getaran hati kalimat Allah-Allah dengan tata cara tersebut diatas. Setelah urutan pembacaan dzikir yang dibaca secara bersama antara mursyid dan murid selesai, aktifitas khususiyah diakhiri dengan pembacaan do'a khushusuyah oleh mursyid. ${ }^{29}$

Dengan tata cara dzikir tersebut, maka sama halnya dengan mengamalkan amalan-amalan para guru dan pahalnya disamakan oleh Allah seperti pahalnya para guru, dan mendapat faedah yang sempurna dengan apa yang sudah dijanjikan oleh Allah dan diwahyukan Nabi Muhammad Saw. Dan akan dikumpulkan diakhirat bersama orangorang yang selamat.

\section{c) Aktivitas Bulanan (Manaqiban)}

Pembacaan manaqib adalah pembacaan mengenai biografi sejarah atau riwayat hidup Syeikh Abdul Qadir al Jailani yang berbentuk bahasa arab. Tata cara pembacaannya adalah mursyid membaca lafadz-lafadz manaqib, sedangkan para jama'ah mendengarkan dengan seksama sambil sesekali secara bersama-sama menirukan lafadz yang diucapkan oleh mursyid. Lafadz yang dibaca itu adalah Yaa hadiyu yaa 'alimu yaa khabiru yaa mubin. dan lafadz yaa rabbana bil haikali al nurooni, al baari

\footnotetext{
${ }^{29}$ Penjelasan wirid khataman/khususiyah tharekat mu'tabaroh qodiriyyah wan naqsabandiyyah, yan berada di desa sungai pasir, yan dibawa oleh syekh M. Aly Bahruddin dari pesantren at taqwa (pesat) cabean pasuruan (cakep). Lihat Kitab Pembinaan Moral Untuk Menjadikan Manusia Seutuhnya Oleh Jam'iyah Ahlith Thoriqoh Mu'tabaroh Qodiriyah Wan Naqsyabandiyah Cabean Kejayan Pasuruan Jawa Timur Indonesia. h. 149-152.
}

'abdi al Qaadiril Jilaani. Aktifitas ini dilaksanakan setiap satu bulan, yaitu tanggal sebelas menurut perhitungan tahun Hijriyah, bertepatan dengan wafatnya Syeikh Abdul Qadir al Jilani. Seperti yang diutarakan oleh ustadz Sya'roni : "Kegiatan tarekat adalah pembacaan manaqib Syaikh Abdul Qadir Al-Jailani dan Istighasah yang dilakukan setiap tanggal sebelas bulan hijriyah." 30

Aktifitas ini biyasanya diikuti oleh para pengikut tarekat di Desa Sungai Pasir. Selain aktifitas rutin yang dilaksanakan setiap bulan, pada tangal 11 hijriyah, peringatan wafatnya Syeikh Abdul Qadhir al Jailani di Desa Sungai Pasir juga diadakan setiap tahun (yang disebut haul Akbar). Dalam acara tahunan ini melibatkan semua anggota tarekat Qadhiriyah wan Naqsyabandiyah di daerah Kalimantan Tengah terutama di Desa Sungai Pasir. ${ }^{31}$

Tujuan dari pembacaan manaqib ini adalah sebagai bukti kecintaan dan penhormatan para murid tarekat terhadap gurunya yaitu Syeikh Abdul Qadir al-Jailani, yang telah memberikan pengajarannya. dengan segenap perjuangan sehingga saat ini sangat bermanfaat bagi umat. Seperti halnya yang telah ditegaskan oleh ustadz Sya'roni :

"Tanda-tanda yang lain seorang murid akan senang membaca kisah-kisah Gurunya, kalau kodiriyah senag membaca

${ }^{30}$ Aktivitas yang dilakukan masyarakat di Desa Sungai Pasir setiap bulan sekali, wawancara dengan Ustadz Sya'roni pada senin, 12 agustus 2012. yang dilihat.

${ }^{31}$ Dari data lapangan dan pengamatan 
kisahnya dalam manakib Sekh Abdul Khadir Al-Jaelani, kalau dalam tarekat AnNaksabandiyah senag membaca manakibnya atau kisahnya Sekh Bahaudin pendiritarekat tersebut, dan sebagai umatnya Nabi Muhammad senag membaca solawat dan tibak yang didalamnya mengandung hikayahhikayah Nabi Muhammad saw." Dalam acara tahunan ini materi acaranya bukan hanya pembacaan manaqib, namun dirangkai dengan acara yang lain seperti khatmil Qur'an, Pembacaan tahlil, pembacaan shalawat, dan pengajian umum. $^{32}$

\section{Pemahaman Anggota Tarekat Terhadap Kehidupan Bermakna}

Sesuai dengan data yang terdapat di lapangan, didapat suatu kesimpulan, bahwa pengikut thariqah Qadiriyah Wan Naqsabandiyah di Desa Sungai Pasir sangat beragam menanggapi tentang makna (arti) hidup itu sendiri, misalnya ibu Hastatik mengatakan bahwa:

"Yang dinamakan makna hidup dalam kehidupan adalah sesuatu yang dikembangkan dalam kehidupan sehari-hari, dengan bersungguh-sungguh dengan niat menjalankan perintah dan menjauhi larangan Allah SWT. ${ }^{33}$ Sedangkan menurut bapak Juhan makna hidup adalah sesuatu yang dipahami, dan bagaimana menjalankannya dengan hidup yang benar dan berpegang

\footnotetext{
32 Wawancara dengan Ustadz Sya'roni. 33Wawancara dengan Ibu Hastatik sebagai salah satu pengikut tarekat Qadiriyah Wan Naqsyabandiyah Desa Sungai Pasir Kecamatan Pantai Lunci Kabupaten Sukamara pada Selasa, 30 oktober 2012.
}

teguh pada ketentuan Allah SWT". 34

Dengan adanya kegiatan Tarekat di desa ini akan lebih mudah bagi kita dalam menjalani kehidupan, karena disitu sudah ada tata cara yang mudah untuk kita pahami dan kita mengerti untuk lebih mudah dalam mendekatkan diri kepada Allah Swt. Sementara itu abang Amri mengatakan bahwa:

"Makna hidup adalah apa yang dapat dijalankan di dunia dengan benar dan sungguh-sungguh dalam menempuh hidup yang mulia dan Makna hidup setiap manusia dapat ditentukan sendiri olehnya, karena manusia memiliki kebebasan yang hampir tidak terbatas. Dari kebebasannya manusia dapat memilih makna atas setiap peristiwa yang terjadi dalam diri, apakah itu makna positif atupun makna yang negatif. Dan makna positif ini lah yang dimaksud dengan hidup bermakna. ${ }^{35}$ Lain halnya dengan Ibu Maimunah mengatakan bahwa makna hidup adalah perjalanan hidupnya manusia banyak sekali merekam pengalaman dalam sepanjang hidupnya, baik atau buruknya pengalaman itu semua terekam dalam otak kita. Dari pengalamanpengalam itu ada sebagian orang

${ }^{34}$ Wawancara dengan Bapak Juhan selaku jama'ah tarekat di desa Sungai Pasir pada Jum'at, 02 september 2012 di masjid Ihsanul Aqso.

35Wawancara dengan Bang Amri selaku jama'ah tarekat di desa Sungai Pasir pada Senin, 29 oktober 2012 . 
yang belajar dari pengalaman tersebut dan ada yang menjadi terpuruk dengan kejadian masa lalunya atau biasa kita sebut trauma. Namun dari kesemuanya itu sebenarnya ada suatu hal akan akan dapat memotivasi manusia untuk menyikapi semua permasalah, cobaan yang menimpanya. ${ }^{36}$

Dengan data yang di dapat dari beberapa masyarakat di desa Sungai Pasir, bahwa Pengalaman makna hidup dalam aktivitas tarekat Qodiriyah Wan Naqsabandiyah berakar pada kerangka kehidupan yang penuh dengan keagamaan, dimana peruses pencapaian tujuan ini diperoleh melalui peruses latihan mujahadah yang maksimal dan selalu mendekatkan diri kepada Allah Swt. Seperti dikatakan Ust. Sya'roni bahwa:

"Khususnya TQN di desa Sungai Pasir, para pengikut terekat mengamalkan ajaran TQN dalam rangka ibadah dengan penuh keikhlasan dan kesungguhan dalam membersihkan hati, karena kebersihan hati adalah wujud eksistensi manusia, cara membersihkan hati dengan cara berdzikir yang benar dan tepat. Dengan rangkaian amalan tarekat adalah dzikruAllah, baik dzikir jahr maupun dzikir khofi , dzikir tersebut sudah diatur dan dilaksanakan

36Wawancara dengan Ibu Maimunah pada Minggu, 28 oktober 2012. setelah mendapat bae'at (talqin dzikir) terlebih dahulu". ${ }^{37}$

\section{Hubungan antara Guru dan Murid}

Seperti halnya pembahasan di atas, tarekat yang ada di desa Sungai Pasir secara umum belum memiliki struktural yang terbentuk dengan jelas. Nilai kegiatan yang dijalankan hanya masih berdasarkan atas nilai kultur yang terikat dalam tradisi yang dilakukan. Pada pembahasan hubungan antara guru dan murid tarekat ini merupakan pelengkap dalam menjelaskan unsur bentuk ajaran yang memiliki pengaruh terhadap proses pembentukan anggota tarekat dalam memahami kehidupan. Ikatan antar Guru Mursyid dengan murid, menjadi salah satu hubungan yang disakralkan, namun bukan merupakan sebuah penglihatan buta. Hal ini diyakini sebagai sebuah perilaku yang mulia atau yang disebut dengan akhlakul kharimah. Lebih lanjut dijelaskan oleh Ust. Budiono bahwa:

"Sebagai murid tarekat hanya satu yang dilakukan yaitu sam'an watoatan, taat terhadap Guru melebihi taat terhadap yang lain maksudnya guru sebagi ulama yang benar-benar diyakini sebagai pewaris para nabi. Yang dilakukan oleh orang yang ikut tarekat sangat beratsebenarnya, karena mereka wajib benar-benar menjaga adhap terhadap Guru, perkataannya tidak boleh dibantah, siapapun murid tarekat yang mengucapkana

${ }^{37}$ Wawancara dengan Ust. Sya'rini selaku badal mursyid di desa Sungai Pasir Pada Jum'At, 10 November 2012 
terhadap Gurunya, maka murid semacam itu tidak akan selamat". ${ }^{38}$

Demikian halnya mengenai prasangka terhadap guru juga harus didasarkan pada prasangka yang selalu mengarah pada sikap positif. Dan apapun yang diperintahkan oleh guru mursyid dipandang sebagai suatu bentuk anjuran yang harus dilaksanakan. Demikian halnya dijadikan sebagai sebuah bentuk pendidikan untuk selalu memberikan perilaku perseptual yang positif di masyarakat. Pola hubungan seperti ini bisa dikategorikan sebagai indicator dari fungsi doktrinal tarekat, yang berhubungan dengan fungsi tarekat secara umum yaitu menjaga kesinambungan antara agama dan masyarakat.

\section{DAFTAR PUSTAKA}

At-Tafzani, Abu al-Wafa', Sufi dari Zaman Ke Zaman: Suatu Pengantar Tentang Tasawuf, (Bandung: PUSTAKA, 1997).

Sumbangan Tasawuf pada Pendidikan Medium (Malaysia: tp.).

Aceh, Abu Bakar, Pengantar Ilmu Tarekat, ( Solo: Ramadhani, 1996). Kunci Pembuka Dada, terj. A. Shahibul Wafa Tajul Arifn, Miftah al- Shudur Juz I, (Sukabumi: Kotamas, t.th).

Abu Abdillah Muhammad ibn Isma'il alBukhari, Shahih Bukhari, Juz III, (Semarang: Thaha Putra, T.th).

${ }^{38}$ Wawancara dengan Ust. Budiono selaku badal mursyid di desa Sungai Pasir Pada Senin, 13 November 2012
Ansari, Abdul Haq, Muhammad, Antara Sufisme dan Syari'ah, (Jakarta : Rajawali, 1990).

Al-Faqir, Sabilus Salikin, Jalan Para Salik; Panduan Bagi Salik Thatekat Naqsabandiyah Kujaddadiyah Khalidiyah, (Pandean Sengonagung Porwosari Pasuruan,: Pondok Pesantren Ngalah, 2012 ).

Algar, Hamis, "Silent Vokal Dhikr in the Naqsabandi Order", dalam "Akten des VII Kongreses fir Arabistik und Islam wissenschat Gottingen", ed. Albert Dietrich (Gottingen, 1976).

Al-qathani, Said bin musfir, buku putih Syaikh abdul qodir jailani, cel. 1. Terj. Munirul abidin, (Jakarta: pt darul falah, 2003).

Abdullah Haddad, Allamah Sayid, Thariqah Menuju Kebahagiaan, trj. Risalah al-Mu'awanah Wal Mudzaharah Wal Muwazarah Lir-Raghibin Minal Mukminin Fi Suluk Thariq al-Akhirah, (Bandung: Mizan, 1986).

Arikunto, Suharsimi, Prosedur Penelitian; Suatu Pendekatan Praktik, (Jakarta: Rineka Cipta, 1992).

Ardhani, Muhammad, Tarekat dan Kejawen Sepentas Tentang Tasawuf dan kebatinan Jawa, dalam Pesantren. (Jakarta: P3M).

Adi, Rianto, Metodologi Penelitian Social Dan Hokum, edisi 1. (Jakarta: Granit, 2004).

Asmaran As, Pengantar Studi Tasawuf, (Jakarta: PT Raja Grafindo Persada, 1994).

Amsrong, Amatullah, Kunci Memasuki Dunia Taswuf, (Bandang: Mizan, Cet. II, 1998). 
Bruinessen, Martin van, Tarekat Naqsyabandiyah di Indonesia (Bandung: Mizan, 1994).

Bastaman, H.D., Logoterapi: Psikologi Untuk Menemukan Makna Hidup dan Meraih Hidup Bermakna, (Jakrta: PT Raja Grafindo Persada, 2007).

Bastaman, Hanna Djumhana, Integrasi Psikologi Dengan Islam Menuju Psokologi Islam, (Yogyakarta: Kerja Sama Antara Yayasan Insan Kamil \& Pustaka Pelajar, 1995).

Baihaqi, MIF, Pisikologi Pertumbuhan: Kepribadian Sehat Untuk Mengembangkan Oftimesme, (Bandung: PT Remaja Rosdakarya, 2008).

Boeree, George C., Personality Theories: Melacak Kepribadian Anda Bersama Psikoloqg Dunia, (Jogjakarta: Prismasophie, 2010).

Bungin, Burhan, Metodologi Penelitian Sosial, (Surabaya: Air Langga, 2001).

Bakker, Anton, Metode Penelitian Filsafat, (Yogyakarta: Kanisius, 1990).

Dasuki, Ensiklopedi Islam IV, (Jakarta. P.T. Ikhtiar Baru Van Hoeve, 1993).

Endang, Turmudi,,Perselingkuhan Kiai dan Kekuasaan. (Yogyakarta. LkiS : 2004).

Fathurahman, Oman, Menyoal Wahdatul Wujud, (Bandung : Mizan, 1999).

Frankl, E.Victor, Logoterapi Terapi Psikologi Melalui Pemaknaan Eksistensi, Terj. Man's Search Meaning: An Introduction to Logotherapy, ( Jogjakarta: Kreasi Wacana, 2006).

Franz Magnis Suseno, Kuasa dan Moral, (Jakarta: Gramedia Pustaka Utama, 2001).
Heru Adi Sutomo, Perbandingan Ajaran Sufi Dengan Kebatinan Jawa, (Surabaya: Bina Indra Karya. 1987).

Hasan, Iqbal, Analisis Data Penelitian Dengan Statistik, (Jakarta: PT. Bumi Aksara, 2008).

Hajar, Ibnu, Dasar-Dasar Metodologi Penelitian Kuantitatif Dalam Penelitian, (Jakarta: Raja Grafindo Persada, 1996).

Hasan, purwakania, Aliah B., Psikologi Perkembangan Islam: Menyingkap Rentang Kehidupan Manusia Dari Prakelahiran Hingga Pascakematian, Ed. 1. (Jakarta: PT Raja Grafindo Persada, 2006).

Rasyidi H.M. Islam Untuk Disiplin IImu Filsafat. (Jakarta: Proyek Pembinann Pendidikan Perguruan tinggi umum. 1984).

Jamil, Muchsin, Tarekat dan Dinamika Sosial Politik : Tafsir Sosial Sufi Nusantara, (Yogyakarta: Pustaka Pelajar, 2005).

Kitab Pembinaan Moral Untuk Menjadikan Manusia Seutuknya Oleh Jam'iyah Ahlith Thoriqoh Mu'tabaroh Qodiriyah Wan Naqsabandiyah Cabean Kejayan Pasuruan Jawa Timur Indonesia.

Kafie, Jamaluddin, Tasawuf Kontemporer, (Jakarta: Mutiara Al Amien Prenduan, 2003).

Layla binti Abdillah, Mewaspadai Tasawuf, (Jakarta: PT. Wacanalazuardi Amanah 1995).

Moloeng, Lexy J., Metodologi Penelitian Kualitatif, (Bandung: Remaja Rosdakarya, 2007, cet. XXIV). 
Mulyati, Sri, Tarekat -Tarekat Muktabarah di Indonesia, (Jakarta : Kencana, 2004).

Mir Valiuddin, Zikir dan Kontemplasi dalam Tasawuf, (Bandung: Pustaka Hidayah, 1996).

Madjid, Nurcholid, Bilik-Bilik Pesantren: Sebuah Potret Perjalanan, (Jakarta: Paramadina, 1997).

Nasution, Harun, Tarekat Qodriyah Naqsabandiyah; Sejarah, AsalUsul, dan Perkembangannya, Institut Agama Islam Latifah Mubaroqiyyah (IAILM)

Tasikmalaya-indonesia,

(Bandung: PT. Remaja Rosdakarya, 1991).

Praja, Juhaya S., Model Tasawuf Menurut Syari'ah, (Tasikmalaya :PT Latifah Press,: Pondok Pesantren Suryalaya.cet I.1995).

Penelitian Kolektif, Yang Ditulis Oleh Seorang Dosen Ushuluddin Iain Walisongo Semarang, Zainul Adzfar yang berjudul "Epistemologi Pengalaman Keagamaan Dalam Tradisi Tarekat (Stady Pengalaman Keagamaan Ikhwan Tarekat Qadiriyah Wa Naqsabandiyah (TQN) di Suryalaya)",( Semarang: 2006).

Riyanto, Yatim, Metodologi Penelitian Pendidikan Suatu Tinjauan Dasar, (Surabaya: SIC, 1996).

Rasihon Anwar \& Mukhtar Solihin, Ilmu Tasawuf, (Bandung: CV. Pustaka Setia, 2000).

Siraj, Agil, Said, Tasawuf Sebagai Krisis Sosial Mengedepankan Islam Sebagai Inpirasi Bukan Aspirasi, (Bandung: PT Mizan Pustaka, 2006).

Shodiq, Ja'far, Pertemuan Antara Tarekat dan NU Stadi Hubungan
Tarekat dan Nahdhatul Ulama Dalam Konteks Komunikasi Politik 1955-2004, (Yogyakarta: Pustaka Pelajat, 2008).

Sulyati, Sri, et'al., “Mengenal Dan Memahami Thariqah-thariqah Muktabarah di Indonesia", (Jakarta: Prenada Media, 2004).

Solihin M., Melacak Pemikiran Tasawuf Di Nusantara, (Jakarta: PT Raja Grafindo Persada, 2005).

Schimmel, Annemarie, Mystical Dimension of Islam, Terj. S. Djoko Damono, dkk, dengan judul Dimennsi Mistik dalam Islam, (Jakarta: Pustaka Firdaus, 1986).

Sofiatun, Umi, Skripsi “Kekhusyu'an Shalat Pada Pengikutthariqah Qadiriyah Naqsabandiyah (Studi Kasus di Desa Babadan Limpung Kecamatan Limpung Kabupaten Batang)" Fakultas Ushuluddin, (Semarang, 2007).

Syaikh Muhammad bin Yahya At-Tadafi Syaikh Abdul Qodir Jailani: Mahkota Para Aulia Kemuliaan Hamba yang Ditampakan-Nya, (Jakarta: Prenada, 2005).

Skripsi Anik Handayani, Konsep Dzikir Dalam Tarekat Qodiriyah Wan Naqsabandiyah, th 1999.

Tohir, Moenir Nahrowi, Menjelajahi Eksistensi Tsawuf Meniti Jalan Menuju Tuhan, (Jakarta: PT. As-Salam Sejahtera, 2012).

Umari, Barnawi, Sistematik Tasawuf, (Solo. Ramadhani.1994).

Zohar, D. \& Marshall, SQ: Memanfaatkan Kecerdasan Spiritual dalam Berpikir Integralistik dan Holistik untuk Memaknai Kehidupan., (Bandung: Penerbit Mizan, 200). 